\title{
Development-Dependent Expression of Cathepsins D and E in Various Rat Tissues, with Special Reference to the High Expression of Cathepsin E in Fetal Liver
}

\author{
Takashi Kageyama $^{1 *}$, Masae Tatematsu², Masao Ichinose ${ }^{3}$, Naohisa Yahagi ${ }^{3}$, \\ Kazumasa Miki $^{\dagger \dagger}$, Akihiko Moriyama ${ }^{4}$ and Satoshi Yonezawa ${ }^{5}$ \\ ${ }^{1}$ Department of Cellular and Molecular Biology, Primate Research Institute, \\ Kyoto University, Inuyama 484-8506, Japan \\ ${ }^{2}$ First Department of Pathology, Aichi Cancer Center Research Institute, \\ Nagoya 464-8681, Japan \\ ${ }^{3}$ First Department of Internal Medicine, Faculty of Medicine, \\ The University of Tokyo, Tokyo 113-8655, Japan \\ ${ }^{4}$ Division of Biomolecular Science, Institute of Natural Sciences, \\ Nagoya City University, Nagoya 467-8501, Japan \\ ${ }^{5}$ Department of Embryology, Institute for Developmental Research, \\ Aichi Human Service Center, Kasugai 480-0392, Japan
}

\begin{abstract}
The levels of cathepsins $D$ and $E$ in various rat tissues during development were determined with the sensitive assay method we have developed. The level of cathepsin D increased gradually in each tissue during fetal development suggesting the gradual maturation of the lysosomal system in a cell. The level of cathepsin E differed significantly between tissues at various developmental stages. The level in liver increased rapidly from 13-day-gestation fetal stage and decreased gradually at later fetal stages. The level in other tissues such as stomach and spleen began to increase at later fetal stages or the infant stage. Cathepsin E was found in fetal hepatocytes and its gene was hypomethylated when the expression of the gene was elevated. The enzyme was found to be present mainly as a proform suggesting that, after working, an active form is rapidly inactivated.
\end{abstract}

\section{INTRODUCTION}

Proteinases have been implicated in a variety of metabolic processes that create and destroy biologically active proteins and peptides. Proteinases at early developmental stages are thought to be especially important, since various proteinous and peptide growth factors are involved in the growth and differentiation of embryonic or fetal cells and their biological activities are regulated by proteinases through processing and degradation. Some proteinases such as proteasome (Ahn et al., 1991) and collagenase (Reponen et al., 1992) have been shown to be expressed development-dependently. To date, however, information about proteinases which are specific for early developmental stages is much less extensive than that which is known about proteinases in the adult tissues of mammals or other vertebrates.

\footnotetext{
* Corresponding author: Tel. +81-568-63-0578; FAX. +81-568-63-0085.

+ Present address: First Department of Internal Medicine, Toho University School of Medicine, Tokyo 143-8541, Japan.
}

To clarify the roles of proteinases at early developmental stages, we undertook to determine the levels of cathepsins D and $E$ in various fetal tissues of rat and monkey. Cathepsins $D$ and $E$ are known to be the major intracellular aspartic proteinases and are involved in the processing and degradation of intracellular proteins and peptides (Lapresle, 1971; Barrett, 1977; Kageyama, 1995; Kay and Tatnell, 1998). A recent report has shown that cathepsin $\mathrm{D}$ might be involved in activation/inactivation of signaling proteins during development (Saftig et al., 1995). Little is known about the developmental change or role of cathepsin $\mathrm{E}$, although we have reported some preliminary findings that cathepsin $\mathrm{E}$ was detected as a major proteolytic enzyme of the gastric mucosa of rat fetus (Yonezawa et al., 1993) and was appreciable in some tissues of rabbit at late fetal stages (Kageyama, 1993).

Since cathepsins $\mathrm{D}$ and $\mathrm{E}$ have similar general proteolytic activities at an acidic $\mathrm{pH}$, determination of their levels in cells and tissues has been performed by complicated procedures using specific antibodies (Muto et al., 1988; Sakai et al., 1989). We found that they have quite different hydrolytic activities against two peptide substrates, namely, $\beta$-endorphin and sub- 
stance P (Kageyama, 1995), and thus developed a new method for the assay of these cathepsins to determine their levels in various mammalian tissues (Kageyama et al., 1996b).

In this report, we describe the developmental change of cathepsins $D$ and $E$ in various rat tissues determined by the method we have developed. The high level of cathepsin $E$ in the fetal liver was noteworthy and was analyzed in detail using Southern and Northern blotting and immunohistochemistry.

\section{MATERIALS AND METHODS}

\section{Materials}

Substance $P$ and $\beta$-endorphin were purchased from the Peptide Institute, Inc., Minoh, Japan. cDNA for rat cathepsin E (pRT732) was isolated from a cDNA library of rat gastric mucosal mRNA. All other chemicals were of reagent or analytical grade.

\section{Preparation of tissue homogenate}

SD strain rats were mated overnight and pregnancy was confirmed by examination of vaginal smears. The day that sperm were detected was defined as day 0 of gestation. Rat tissues at various developmental stages were homogenized in $0.05 \mathrm{M}$ sodium phosphate buffer, $\mathrm{pH} 7.0$, with a mechanical homogenizer. Each homogenate was centrifuged at $10,000 \times g$ for 20 min and the supernatant was used for PAGE and the assay for proteolytic activity. Each supernatant was mixed with an equal volume of glycerol and kept at $-20^{\circ} \mathrm{C}$ for long-term storage. The amount of protein in the crude homogenate supernatant was determined by the method of Lowry et al. (1951).

\section{Assay of cathepsins $D$ and $E$}

The procedure was based on that described in our previous reports (Kageyama, 1995; Kageyama et al., 1996b). In brief, the reaction mixture contained $0.2 \mathrm{M}$ sodium formate buffer, $\mathrm{pH} 4,1 \mu \mathrm{M} \mathrm{E}-64$, $50 \mu \mathrm{M}$ substance $\mathrm{P} / \beta$-endorphin and an appropriate amount of crude homogenate supernatant. The reaction was incubated at $37^{\circ} \mathrm{C}$ for 1 $2 \mathrm{hr}$ and stopped by the addition of $60 \mu \mathrm{l}$ of $3 \%$ perchloric acid. After removal of the precipitate, the mixture was subjected to HPLC on a column of ODS-120T (Tosoh Corp., Tokyo) to determine the hydrolysis of peptide. The relative specific activity of cathepsins $D$ and $E$ in each tissue was expressed as the amount of hydrolyzed substrate/ $\mathrm{min} / \mathrm{mg}$ tissue protein. Although cathepsin $\mathrm{D}$ is usually present as an active form in a cell, cathepsin $\mathrm{E}$ in each tissue homogenate has been shown to be present mainly as procathepsin E (Kageyama et al., $1996 b)$. The ratio of cathepsin $E$ to procathepsin $E$ was estimated by the difference of substance $\mathrm{P}$ hydrolyzing activity at $\mathrm{pH} 4$ and 5 , since activation of procathepsin $\mathrm{E}$ was rapid at $\mathrm{pH} 4$ and very slow at $\mathrm{pH} 5$ (Kageyama et al., 1992).

\section{Separation of cathepsins $D$ and $E$ in the tissue homogenate and} activity staining

Electrophoretic separation of cathepsins D and $E$ in the crude homogenate was carried out using slab gels of polyacrylamide. The composition of the gel was the same as that described by Ornstein (1964) and Davis (1964). Detection of cathepsins D and E after electrophoresis was performed according to Furihata et al. (1972). Briefly, gels were immersed in $1 \%$ hemoglobin in $0.1 \mathrm{M}$ sodium formate buffer, $\mathrm{pH} 3.5$, for $20 \mathrm{~min}$ at $37^{\circ} \mathrm{C}$, followed by another 2-hr incubation without the substrate solution. The gel was then stained with Coomassie brilliant blue R-250.

\section{Analysis of the methylation of cathepsin E gene}

High-molecular-weight DNA at various developmental stages of the rat liver and stomach was prepared by the method of Gross-Bellard et al. (1973). A sample of $10 \mu \mathrm{g}$ of DNA was digested to completion with Hhal. Separation of fragmented DNA by agarose gel electrophoresis and transfer to nitrocellulose paper was performed by the method of Southern (1975). The fragmented cathepsin E gene was detected with ${ }^{32} \mathrm{P}$-labeled cDNA for rat procathepsin E (pRT732) under high-stringency conditions.

\section{Northern blot analysis}

Total RNA was extracted and purified by the guanidinium thiocyanate-cesium chloride centrifugation method (Chirgwin et al., 1979). $15 \mu \mathrm{g}$ total RNA from the rat liver at various developmental stages were denatured and subjected to electrophoresis in a 1\% agarose gel that contained $1.1 \%$ formamide. After the RNA had been transferred to a Hybond-N membrane (Amersham Int.), the membrane was hybridized with ${ }^{32} \mathrm{P}$-labeled cDNA for rat procathepsin E (pRT732) under high-stringency conditions.

\section{Immunohistochemical analysis}

The tissue was fixed in 10\% phosphate-buffered formalin and embedded in paraffin. The avidin-biotin-peroxidase complex method was used to determine the localization of cathepsin $E$ binding in various tissue sections using anti-rat cathepsin E serum prepared as described previously (Yamamoto et al., 1996). Sections were counterstained with hematoxylin for microscopic examination.

\section{RESULTS}

\section{Developmental change of cathepsins $D$ and $E$ in rat tis- sues}

We have reported levels of cathepsins $D$ and $E$ in various tissues of 1-month-old juvenile rat in a previous paper (Kageyama et al., 1996b). In this report, developmental change in the levels of cathepsins $D$ and $E$ in various tissues was investigated. The results show that the level of cathepsin $D$ in each tissue increased gradually during fetal development and that of cathepsin $\mathrm{E}$ changed significantly during development (Fig. 1). The quite high level of cathepsin $E$ in fetal liver from 14- to 17-day-gestation stages is particularly noteworthy. The level in other tissues such as stomach, spleen, and thymus increased at later fetal stages or the infant stage. Since the liver diverticulum first appears around day 12, this coincided with the time when the level of liver cathepsin $E$ began to increase. Although we did not investigate in detail the change in levels of cathepsins $D$ and $E$ after 1-month-old juvenile stage, the levels of both cathepsins in some tissues such as liver of 3-month-old adult were largely similar to those in respective tissues of 1-month-old juvenile. The levels of cathepsins $D$ and $E$ in serum were also determined (Table 1). The level of serum cathepsin $D$ was high at the fetal stage and decreased to one-half and then one-third at the infant and juvenile stages, respectively. The Level of serum cathepsin E (mainly procathepsin E) was high at the fetal stage but had decreased significantly at the infant and juvenile stages.

Cathepsins $D$ and $E$ in each tissue were visualized by activity staining after PAGE of the crude homogenate (Fig. 2). Throughout development, cathepsin D was present as an active form, whereas cathepsin $E$ was present mainly as a precursor form, namely, procathepsin $E$. The ratio of cathep$\sin \mathrm{E}$ to procathepsin $\mathrm{E}$ was estimated by assays at $\mathrm{pH} 4$ and 5. The active cathepsin $E$ was present at about $5-10 \%$ in each 


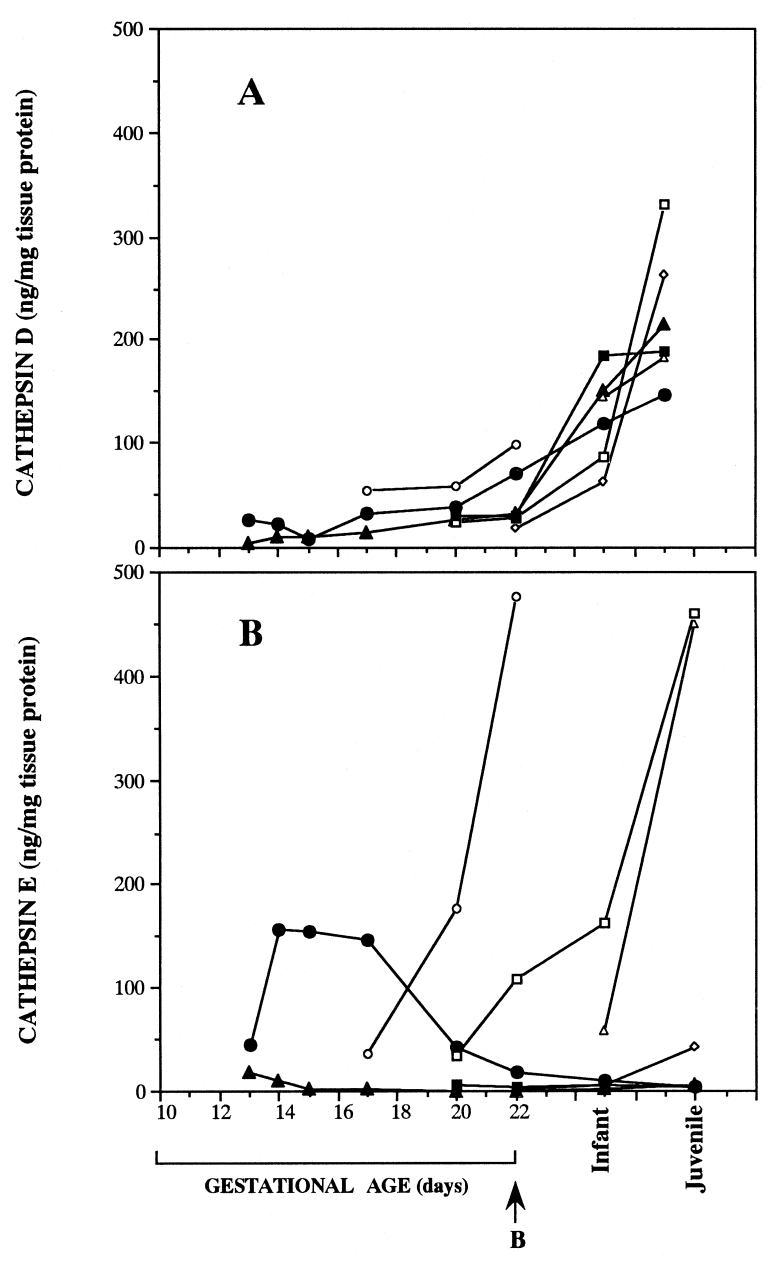

DEVELOPMENTAL STAGE

Fig. 1. Developmental change of the levels of cathepsins $D(\mathbf{A})$ and $\mathrm{E}(\mathbf{B})$ in various rat tissues. $\boldsymbol{\Delta}$, Brain; $\triangle$, thymus; $\diamond$, lung; $\boldsymbol{O}$, liver; $\bigcirc$, stomach; $\square$, spleen; $\square$, kidney. Arrow B shows the time of birth.

Table 1. Levels of cathepsin D and cathepsin $E$ in the serum at three different developmental stages

\begin{tabular}{lccc}
\hline \multirow{2}{*}{ Enzyme } & \multicolumn{3}{c}{ Developmental stage } \\
\cline { 2 - 4 } & $\begin{array}{l}\text { 17-day-gestation } \\
\text { fetus }\end{array}$ & 4-day-old infant & Juvenile \\
\hline & & $\mathrm{ng} / \mathrm{ml}$ serum \\
Cathepsin D & 207 & 102 & 72 \\
Cathepsin $\mathrm{E}^{*}$ & 204 & 24 & 18 \\
\hline
\end{tabular}

* The major form in the serum was procathepsin E.

tissue of the fetus and juvenile, except that a high ratio of cathepsin E (more than 40\%) was found in some tissues such as juvenile kidney.

\section{Methylation of the cathepsin E gene}

For methylation analysis, a methylation-sensitive restriction enzyme Hhal was used. The enzyme recognizes the GCGC sequence and does not hydrolyze this sequence if
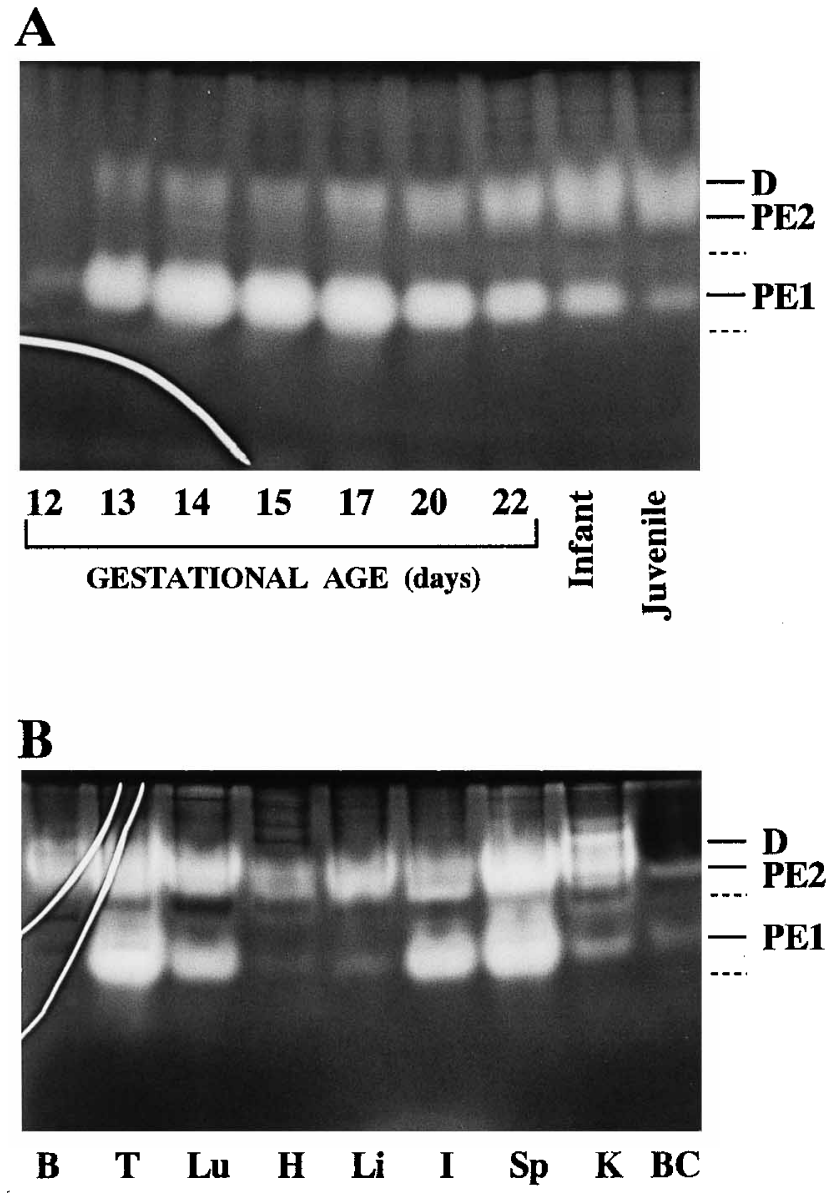

Fig. 2. Activity staining of rat cathepsins $D$ and $E$. A portion of the crude homogenate supernatant was subjected to electrophoresis on a 10\% polyacrylamide gel in Tris-glycine buffer, $\mathrm{pH}$ 8.3. After electrophoresis, activities of cathepsins $\mathrm{D}$ and $\mathrm{E}$ were stained by the method of Furihata et al. (1972) except that the incubation with hemoglobin was carried out at pH 3.5. (A) Electrophoresis of liver homogenates prepared at various developmental stages. (B) Electrophoresis of various tissue homogenates of 1 -month-old juvenile rat. Horizontal symbols are: $B$, brain; $T$, thymus; Lu, lung; $H$, heart; Li, liver; I, intestine; Sp, spleen; K, kidney; BC, blood cells. Vertical symbols were: D, cathepsin D; PE1 and PE2, procathepsin E monomer and dimer, respectively. Dashed lines show the positions of cathepsin E dimer (upper) and monomer (lower), respectively. Since cathepsin E was present in lower amounts than procathepsin E, it could hardly be visualized in most tissues, except for a few such as juvenile kidney.

cytosine is methylated. It is known that genes are usually methylated in their inactive states and demethylated when expressed (Cedar, 1988). By Southern blot hybridization of Hhal-digested DNA of rat liver at various developmental stages, the number of lower-molecular-weight DNAs were found to be higher at 13 17-day-gestation fetal stages than at infant and juvenile stages (Fig. 3A). This result showed that hypomethylation of the cathepsin $E$ gene occurred in liver cells at 13 17-day-gestation fetal stages and was consistent with the results of high levels of cathepsin $E$ at these developmental stages. When stomach DNA was analyzed, the gene was gradually demethylated during fetal development being con- 
A

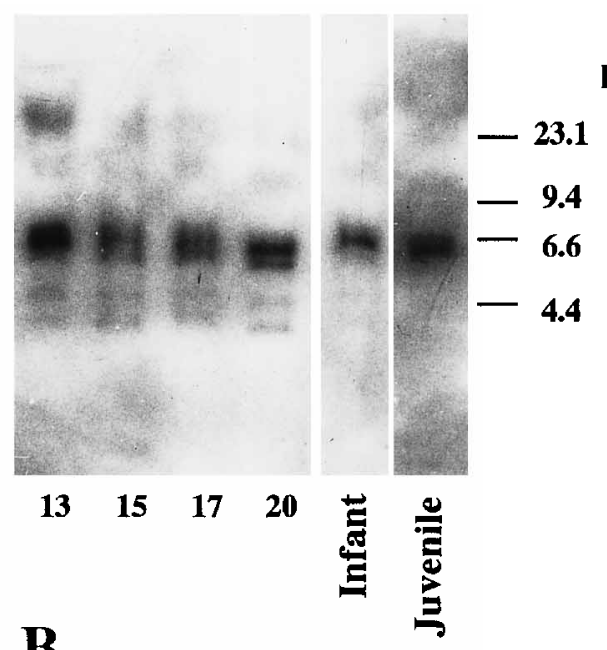

B
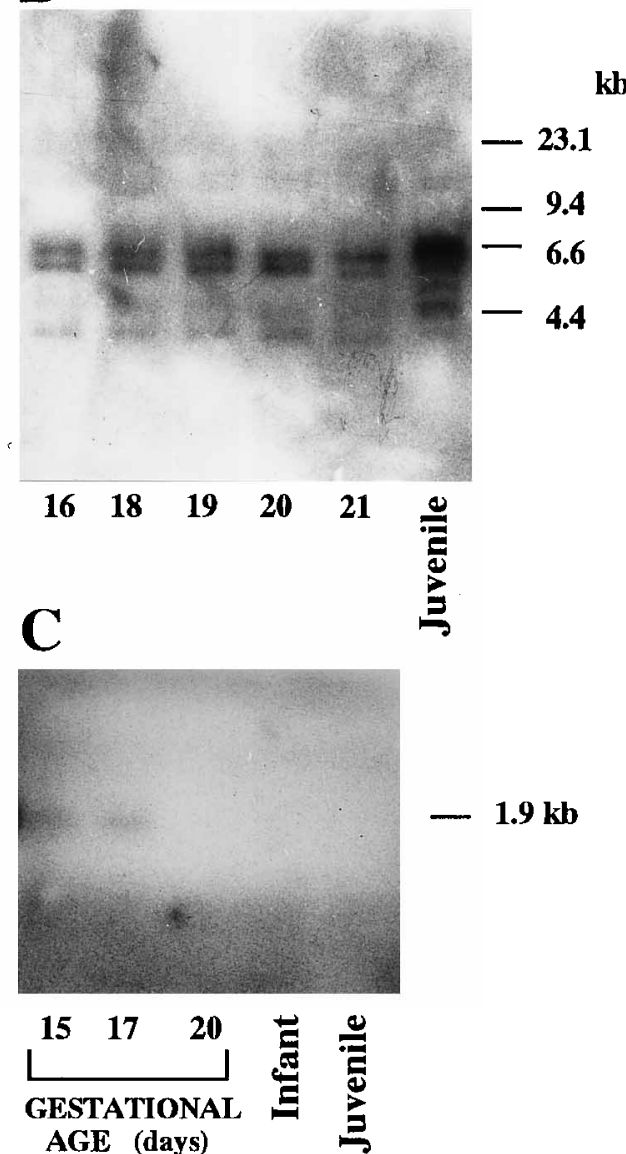

\section{DEVELOPMENTAL STAGE}

Fig. 3. Southern blot hybridization of high-molecular-weight DNAs from liver $(\mathbf{A})$ and stomach $(\mathbf{B})$ at various developmental stages of rat. The amount of DNA applied was $10 \mu \mathrm{g}$. Restriction enzymes used were Hhal. (C) Northern blot hybridization of total RNA from rat liver. The amount of total RNA applied was $15 \mu \mathrm{g}$. After hybridization with ${ }^{32} \mathrm{P}$-labeled cDNA for rat cathepsin $\mathrm{E}$, each membrane was washed under high stringency conditions. sistent with the change of level of gastric cathepsin E (Fig. 3B).

\section{Expression of the cathepsin E gene}

Expression of the mRNA for cathepsin $E$ was examined in fetal liver. A band of mRNA of about $1.9 \mathrm{~kb}$ was detected at 15-day and 17-day-gestation fetal stages being consistent with the high level of activity of cathepsin E at these stages (Fig. $3 C$ ). The size of mRNA for rat cathepsin $E$ was the same with those for guinea pig (Kageyama et al., 1992) and rabbit (Kageyama, 1993) cathepsins E. No appreciable band was observed at later stages, indicating that the expression of the cathepsin $\mathrm{E}$ gene was quite weak at these stages.

\section{Immunohistochemical localization of cathepsin E}

Sections of livers from 14- and 17-day-gestation fetus, 4-day-old infant, and 1-month-old juvenile were stained immunohistochemically using anti-cathepsin E serum (Fig. 4). Stained cells were detected in 14-day and 17-day-gestation fetuses. Although liver contained various types of cells, hepatocytes were stained exclusively showing that liver cathepsin E was synthesized in these cells.

\section{DISCUSSION}

The developmental change in levels of cathepsins $D$ and E was clarified in various rat tissues. First, we discuss the results of cathepsin D. In our previous report (Kageyama et al., 1996b), the level of cathepsin $D$ at 1-month-old juvenile stage was determined. In the present report, the level of cathe$p \sin D$ at various fetal and infant stages was investigated and it increased gradually during fetal development. Since cathepsin D is known to be localized in lysosomes (Barrett, 1977), this result suggests that the lysosomal system is incomplete at fetal stages. Cathepsin D at the fetal stage might be less essential for processing or degradation of intracellular proteins than at infant and juvenile stages. Indeed, mice deficient in cathepsin D survive during fetal development but die around 1 month after birth (Saftig et al., 1995).

In the case of cathepsin E, the level in each tissue changed significantly during development. To date, tissue distribution of cathepsin $\mathrm{E}$ in adult or juvenile rats has been clarified and high levels were found in stomach, thymus, spleen, and bone marrow (Muto et al., 1988; Sakai et al., 1989; Yonezawa and Nakamura, 1991; Bennett et al., 1992; Yonezawa et al., 1993). The enzyme is thought to be involved to varying degrees in the physiological activities of these tissues (Lapresle, 1971; Yonezawa et al., 1987; Finzi et al., 1993; Nakanishi et al., 1994). At early fetal stages, a high level in liver was particular noteworthy. This high level was thought to be due to the activation of the cathepsin E gene as suggested by the hypomethylation of the liver cathepsin $E$ gene. The transcriptional activity of some tissue-specific genes has been shown to be controlled by the extent of methylation (Cedar, 1988). Cathepsin E might have an important physiological role in fetal liver, such as the regulation of liver development through 

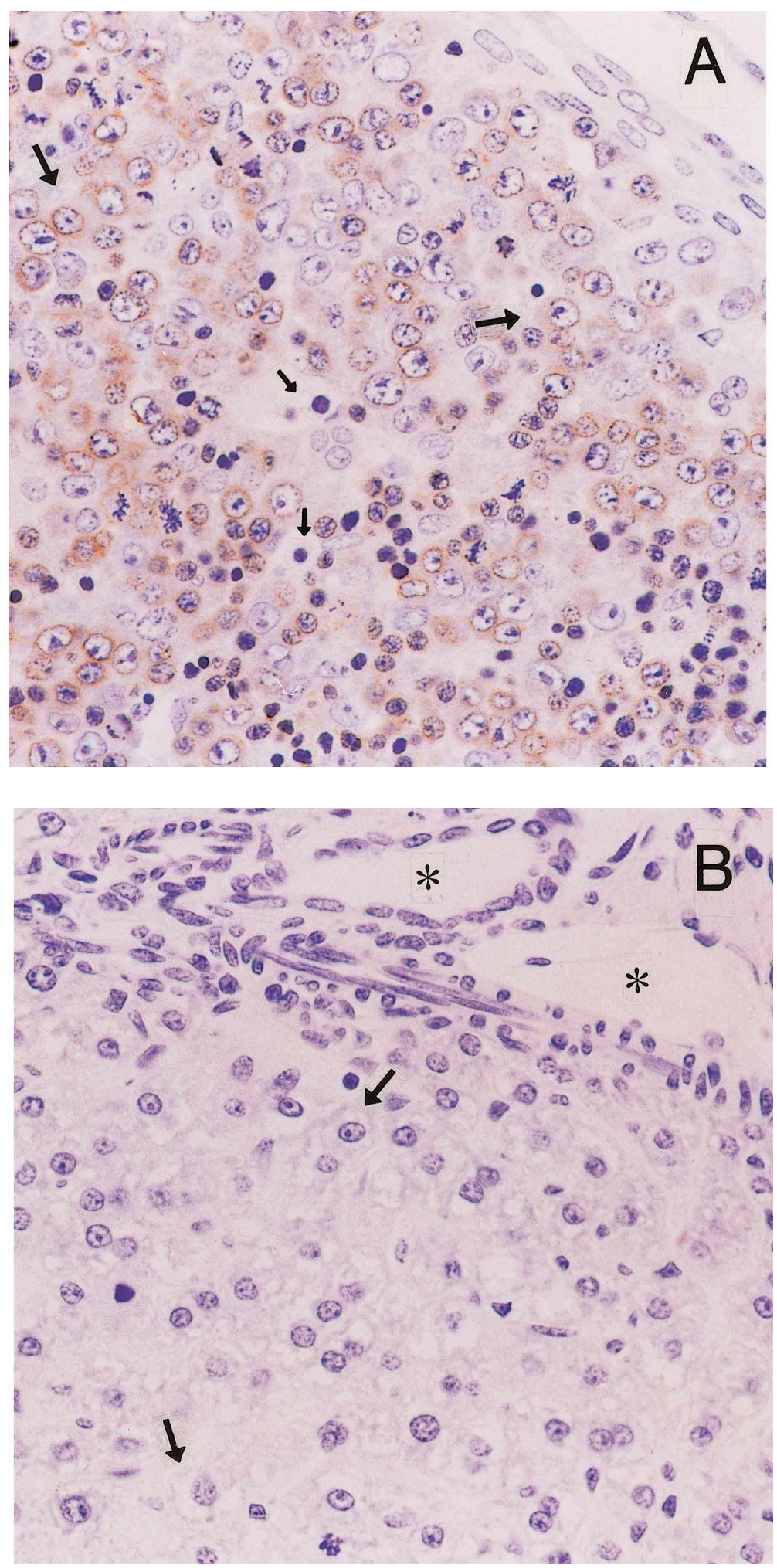

Fig. 4. Localization of cells that produce cathepsin $E$ in rat liver of a 14-day-gestation fetus (A) and 1-month-old juvenile (B). The results of 17day-gestation fetus and 4-day-old infant were similar overall with those of the 14-day-gestation fetus and 1-month-old juvenile, respectively, and are not shown. Large and small arrow marks show hepatocytes and hemopoietic cells, respectively. Asterisks indicate bile ducts. Magnification, $\times 400$. 
activation/inactivation of signaling proteins, since the enzyme has been shown to have high specificity for some bioactive peptides and precursor proteins that are involved in signal transduction and growth (Lees et al., 1990; Kageyama, 1993, 1995; Kageyama et al., 1995, 1996a). The localization of the enzyme in hepatocytes would favor this hypothesis. The enzyme might also be involved in regulating hematopoiesis at fetal stages since liver is known to be the major hematopoietic tissue in the fetus.

Cathepsin E was found to be present in each tissue mainly as a proform. Cathepsin $\mathrm{E}$ is synthesized as preproform and, after removal of the pre-piece, the proform is transported to the endoplasmic reticulum and endosomes (Yonezawa et al., 1988; Saku et al., 1991; Finley and Kornfeld, 1994). Procathepsin E might be stored in these organelles, be activated to cathepsin $\mathrm{E}$ in an acidic microenvironment, and act on various proteins and peptides. Since cathepsin $E$ is unstable under neutral and weakly alkaline conditions (Kageyama et al., 1992), the enzyme might be degraded rapidly after working. This process of activation and degradation is thought to be important to regulate the activity of cathepsin $E$ in a cell.

The hypothesis that procathepsin $E$ itself is essential at the fetal stage could not be excluded. Recently, rat pepsinogen has been shown to be a candidate for growth factors that stimulate the proliferation of gastric epithelial cells (Kishi et al., 1997). Since cathepsin $E$ is evolutionarily closest to pepsinogens between non-pepsinogen aspartic proteinases (Kageyama et al., 1992), procathepsin E might serve as a growth factor in fetal liver and gastrointestinal tissues and stimulate the development of these tissues. High levels of procathepsin $\mathrm{E}$ in fetal serum might corroborate the possibility of this hypothesis. If this is the case, since liver originates from the gastrointestinal tract, procathepsin E might act specifically on tissues of gastrointestinal origin.

\section{ACKNOWLEDGMENT}

This work was supported in part by a Grant-in-Aid from the Ministry of Education, Science, Sports and Culture of Japan (No. 09640805).

\section{REFERENCES}

Ahn JY, Hong SO, Kwak KB, Kang SS, Tanaka K, Ichihara A, Ha DB, Chung CH (1991) Developmental regulation of proteolytic activities and subunit pattern of $20 \mathrm{~S}$ proteasome in chick embryonic muscle. J Biol Chem 266: 15746-15749

Barrett AJ (1977) Cathepsin D and other carboxyl proteinases. In "Proteinases in Mammalian Cells and Tissues" Ed by Barrett AJ, Elsevier/North-Holland Biomedical Press, Amsterdam, pp 209248

Bennett K, Levine T, Ellis JS, Peanasky RJ, Samloff IM, Kay J, Chain BM (1992) Antigen processing for presentation by class II major histocompatibility complex requires cleavage by cathepsin E. Eur J Immunol 22: 1519-1524

Cedar H (1988) DNA methylation and gene activity. Cell 53: 3-4

Chirgwin JM, Przybyla AE, MacDonald RJ, Rutter WJ (1979) Isolation of biologically active ribonucleic acid from sources enriched in ribonuclease. Biochemistry 18: 5294-5299
Davis BJ (1964) Disc electrophoresis. II. Method and application to human serum proteins. Ann N Y Acad Sci 121: 404-427

Finley EM, Kornfeld S (1994) Subcellular localization and targeting of cathepsin E. J Biol Chem 269: 31259-31266

Finzi G, Cornaggia M, Capella C, Fiocca R, Bosi F, Solcia E, Samloff IM (1993) Cathepsin E in follicle associated epithelium of intestine and tonsils: localization to $\mathrm{M}$ cells and possible role in antigen processing. Histochemistry 99: 201-211

Furihata C, Kawachi T, Sugimura T (1972) Premature induction of pepsinogen in developing rat gastric mucosa by hormones. Biochem Biophys Res Commun 47: 705-711

Gross-Bellard M, Oudet P, Chambon P (1973) Isolation of high-molecular-weight DNA from mammalian cells. Eur J Biochem 36 : 32-38

Kageyama T (1993) Rabbit procathepsin E and cathepsin E. Nucleotide sequence of cDNA, hydrolytic specificity for biologically active peptides, and gene expression during development. Eur $\mathrm{J}$ Biochem 216: 717-728

Kageyama T (1995) Procathepsin E and cathepsin E. Methods Enzymol 248: 120-136

Kageyama T, Tanabe K, Koiwai O (1991) Development-dependent expression of isozymogens of monkey pepsinogens and structural differences between them. Eur J Biochem 202: 205-215

Kageyama T, Ichinose M, Tsukada S, Miki K, Kurokawa K, Koiwai O, Tanji M, Yakabe E, Athauda SBP, Takahashi K (1992) Gastric procathepsin $E$ and progastricsin from guinea pig. Purification, molecular cloning of cDNAs, and characterization of enzymatic properties, with special reference to procathepsin E. J Biol Chem 267: 16450-16459

Kageyama T, Ichinose M, Yonezawa S (1995) Processing of the precursors to neurotensin and other bioactive peptides by cathepsin E. J Biol Chem 270: 19135-19140

Kageyama T, Yonezawa S, Ichinose M, Miki K, Moriyama A (1996a) Potential sites for processing of the human invariant chain by cathepsins D and E. Biochem Biophys Res Commun 223: 549553

Kageyama T, Moriyama A, Kato T, Sano M, Yonezawa S (1996b) Determination of cathepsins $D$ and $E$ in various tissues and cells of rat, monkey, and man by the assay with $\beta$-endorphin and substance $P$ as substrates. Zool Sci 13: 693-698

Kay J, Tatnell PJ (1998) Cathepsin E. In "Handbook of Proteolytic Enzymes" Ed by Barrett AJ, Rawling ND, Woessner JF, Academic Press, New York, in press

Kishi K, Kinoshita Y, Matsushima Y, Okada A, Maekawa T, Kawanami C, Watanabe N, Chiba T (1997) Pepsinogen C gene product is a possible growth factor during gastric mucosal healing. Biochem Biophys Res Commun 238: 17-20

Lapresle C (1971) Rabbit cathepsins D and E. In "Tissue Proteinases" Ed by Barrett AJ, Dingle JT, North-Holland Publishing Co, pp 135-155

Lees WE, Kalinka S, Meech J, Capper SJ, Cook ND, Kay J (1990) Generation of human endothelin by cathepsin E. FEBS Lett 273: 99-102

Lowry H, Rosebrough NJ, Farr AL, Randall RJ (1951) Protein measurement with the Folin phenol reagent. J Biol Chem 193: 265275

Muto N, Yamamoto M, Tani S, Yonezawa S (1988) Characteristic distribution of cathepsin $\mathrm{E}$ which immunologically cross-reacts with the $86-\mathrm{kDa}$ acid proteinase from rat gastric mucosa. J Biochem 103: 629-632

Nakanishi H, Tominaga K, Amano T, Hirotsu I, Inoue T, Yamamoto K (1994) Age-related changes in activities and localizations of cathepsins D, E, B, and L in the rat brain tissues. Exp Neurol 126: 119-128

Ornstein L (1964) Disc electrophoresis. I. Background and theory. Ann N Y Acad Sci 121: 321-349

Reponen P, Sahlberg C, Huhtala P, Hurskainen T, Thesleff I, 
Tryggvason K (1992) Molecular cloning of murine 72-kDa type IV collagenase and its expression during mouse development. $J$ Biol Chem 267: 7856-7862

Saftig P, Hetman M, Schmahl W, Weber K, Heine L, Mossmann H, Köster A, Hess B, Evers M, von Figura K, Peters C (1995) Mice deficient for the lysosomal proteinase cathepsin $D$ exhibit progressive atrophy of the intestinal mucosa and profound destruction of lymphoid cells. EMBO J 14: 3599-3608

Sakai H, Saku T, Kato Y, Yamamoto K (1989) Quantitation and immunohistochemical localization of cathepsins $E$ and $D$ in rat tissues and blood cells. Biochim Biophys Acta 991: 367-375

Saku T, Sakai H, Shibata Y, Kato Y, Yamamoto K (1991) An immunocytochemical study on distinct intracellular localization of cathepsin $E$ and cathepsin $D$ in human gastric cells and various rat cells. J Biochem 110: 956-964

Southern EM (1975) Detection of specific sequences among DNA fragments separated by gel electrophoresis. J Mol Biol 98: 503517

Yamamoto S, Yonezawa S, Ichinose M, Miki K, Masui T, Fukushima S, Inoue H, Tatematsu M (1996) Immunohistochemically demonstrated variation in expression of cathepsin $E$ between uracilinduced papillomatosis and N-butyl-N-(4-hydroxybutyl)nitrosamine-induced preneoplastic and neoplastic changes in rat urinary bladder. Virchows Arch 427: 589-594
Yonezawa S, Tanaka T, Miyauchi T (1987) Cathepsin E from rat neutrophils: its properties and possible relations to cathepsin D-like acid proteinase. Arch Biochem Biophys 256: 499-508

Yonezawa S, Fujii K, Maejima Y, Tamoto K, Mori Y, Muto N (1988) Further studies on rat cathepsin E: subcellular localization and existence of the active subunit form. Arch Biochem Biophys 267: 176-183

Yonezawa S, Nakamura K (1991) Species-specific distribution of cathepsin $\mathrm{E}$ in mammalian blood cells. Biochim Biophys Acta 1073: $155-160$

Yonezawa S, Maejima Y, Hagiwara N, Aratani T, Shoji R, Kageyama T, Tsukada S, Miki K, Ichinose M (1993) Changes with development in the expression of cathepsin $\mathrm{E}$ in the fetal rat stomach. Develop Growth Differ 35: 349-356

(Received February 16, 1998 / Accepted March 28, 1998) 